\title{
ANTES, DE LÁ PRA CÁ. AGORA, DAQUI PRA LÁ: FLUXOS MIGRATÓRIOS DO BRASIL PARA PORTUGAL A PARTIR DE 1980*
}

\author{
Aline Lima Santos
}

Resumo: No fim do século XX, a emigração tornou-se um fenômeno importante nas dinâmicas da população do Brasil. O fluxo de brasileiros para Portugal surgiu nesse momento como algo novo e deu conteúdos originais a uma antiga relação. A inversão do fluxo tradicional constitui um novo padrão, com sentido contrário ao que se estabeleceu desde o período colonial até meados do século. Quando Portugal e Brasil pareciam afastar-se, os migrantes brasileiros "descobriram" Portugal como país capaz de oferecer melhores perspectivas de futuro. Analisar estas transformações buscando compreender as suas consequências tanto para o país de origem como para o país receptor é o desafio aqui proposto.

Palavras-chave: território, Estado, população, migrações, Brasil e Portugal.

\section{FIRST, FROM THERE TO HERE. NOW, FROM HERE TO THERE: MIGRATION FLOWS FROM BRAZIL TO PORTUGAL FROM 1980}

\begin{abstract}
At the end of the twentieth century, the emigration has become a significant phenomenon in the brazilian population dynamics. The flow of brazilian population to Portugal emerged, at this moment, as something new, supplying with primary information an ancient relation. The inversion of the traditional flow constitutes itself a new pattern, but in opposite direction from the original movement established since the colonial period until de middle of last century. As Portugal and Brazil seemed to move away from each other, the Brazilian immigrants had discovered Portugal as a nation capable enough to offer better future perspectives. Analyze these transformations, intending to comprehend the consequences to the country of origin, as to the recipient country, is the main purpose of this paper.
\end{abstract}

Keywords: territory, State, population, migration, Brazil and Portugal.

\section{Introdução}

Apesar de originar-se de práticas individuais interessa para a Geografia e demais ciências humanas e sociais considerar o fenômeno migratório em sua dimensão coletiva. Já que:

O que, na verdade, ocorre é que a prática, a práxis, é, antes do mais, uma realidade estrutural, estruturada e estruturante ao mesmo tempo; assim ela depende estreitamente da totalidade social e não o contrário. Os comportamentos dos indivíduos, isto é as práxis individuais, são subordinados, estruturados pela práxis social. A liberdade que é frequentemente reconhecida aos agentes não é outra coisa senão sua participação nas práxis coletivas, por intermédio de uma escolha limitada de opções já incluídas na própria estrutura (SANTOS, 2005, p. 129).

O fenômeno migratório é um elemento constituinte da totalidade social e, por conseguinte, do espaço geográfico.Ele resulta e concomitantemente alimenta a heterogeneidade e desigualdade presentes nos territórios, por isso, a seletividade pode ser destacada como uma de suas características primordiais. Daí ser possível

\footnotetext{
* Este artigo sintetiza problemáticas estudadas durante pesquisa de mestrado que culminou na dissertação intitulada Mudança de vento: a migração do Brasil para Portugal no fim do século XX e início do século XXI. A pesquisa foi realizada sob orientação da $\operatorname{Prof}^{a} \mathrm{Dr}^{\mathrm{a}}$ Rosa Ester Rossini, no Programa de Pós-graduação em Geografia Humana da Faculdade de Filosofia, Letras e Ciências Humanas da Universidade de São Paulo, e defendida em 2010.
} 
identificar no mundo padrões migratórios, isto é, as principais áreas de origem e destino dos fluxos de pessoas.

Cada fase da história, discernível das demais segundo uma combinação única de variáveis, conhece arranjos de fluxos populacionais que the são próprios e que se originam de diferentes situações e condições, bem como sintonizam causas e consequências de maneira complexa, tanto para os lugares de partida, como para os de destino (SANTOS, 2002; SANTOS, 2010). Por isso o tema não se esgota e exige constantes reavaliações e reflexões. Este artigo revisita o fenômeno migratório com a finalidade de contribuir para a compreensão da população brasileira e portuguesa e das dinâmicas sociais, culturais, econômicas, políticas e territoriais desses países a partir da década de 1980.

No fim do século $X X$, a emigração tornou-se um fenômeno importante nas dinâmicas da população do Brasil. O fluxo de brasileiros para Portugal surgiu nesse momento como algo novo e deu conteúdos originais a uma antiga relação. A inversão do fluxo tradicional constitui um novo padrão, com sentido contrário ao que se estabeleceu desde o período colonial até meados do século.

Esta transformação ocorreu no momento em que, após a descolonização da África e da Ásia, Portugal optou pela Europa, ao aderir, em 1986, a Comunidade Econômica Europeia (ROCHA-TRINDADE, 2002). O Brasil, por sua vez, passava por forte crise econômica e política, optou pela América do Sul. Ambos os países abandonavam a ditadura militar e abriam-se economicamente. Quando Portugal e Brasil pareciam afastar-se, os migrantes brasileiros "descobriram" Portugal como país capaz de oferecer melhores perspectivas de futuro (SANTOS, 2010).

Essa inversão insere-se em um contexto mais amplo de reordenamento das migrações internacionais após 1945, o qual, por sua vez, relaciona-se às profundas transformações sociais, políticas, econômicas e espaciais que o mundo passava a conhecer. A partir de então a Europa concentra grande número de imigrantes - provenientes do próprio continente e de outras partes - o que reflete seu papel na divisão internacional do trabalho e sua influência geopolítica (SASSEN, 2003).

Analisar as causas e implicações das migrações internacionais contemporâneas nas relações entre Território, Estado e População, a partir das migrações do Brasil para Portugal é o objetivo aqui presente.

\section{As migrações entre Brasil e Portugal: breve periodização}

É possível determinar três períodos de trânsito de pessoas entre Brasil e Portugal. O primeiro vai de 1822 até meados do século XX, o segundo vai daí até 1980, momento em que se inicia o terceiro, ainda inacabado.

O primeiro período aqui identificado caracteriza-se pela maior intensidade da vinda de portugueses ao Brasil comparativamente ao fluxo no sentido contrário, o qual era bastante restrito. Essa situação perdurou durante séculos, remontando às grandes navegações do século XVI. 
Em todo esse período, o mundo conheceu importantes inovações técnicas que repercutiram também nos meios de transporte e comunicação, culminando em meados do século XX a Europa também se destacava como origem dos principais fluxos migratórios que se direcionavam ao continente americano, à África, Ásia e Oceania. Em 1900 a população europeia representava quase $25 \%$ da população mundial e colaborava intensivamente para a expansão populacional dos povos em todo o mundo por meio das migrações (BARATA, 2003).

Desde os grandes descobrimentos até meados do século $X X$, as migrações foram passando de um contexto de imperialismo, cuja marca principal assenta-se nas relações entre as metrópoles e suas respectivas colônias, para um mundo de Estados nacionais. As metrópoles constituíam-se, em suma, como áreas de origem dos fluxos migratórios, enquanto as colônias, por sua migrações bastante volumosas. Como se sabe, o grande lócus dessas transformações técnicas era o continente europeu. Até

vez, destacavam-se como áreas receptoras. Mesmo com as independências, esse padrão manteve-se pouco alterado.

É principalmente com o início da colonização do Brasil que o fenômeno da emigração adquire relevância sem precedentes em Portugal e torna-se permanente. Embora apresente oscilações conjunturais, a emigração destaca-se em um grande período da história portuguesa como a mais importante vertente dos movimentos migratórios desse país, superando os movimentos internos e as imigrações em termos absolutos e relativos (ROCHATRINDADE，1986; RODRIGUES， 2009). Os portugueses que migraram para o Brasil eram majoritariamente originários do norte do país, como é possível observar na Figura 1.

Figura 1 - Emigração portuguesa por distrito de naturalidade

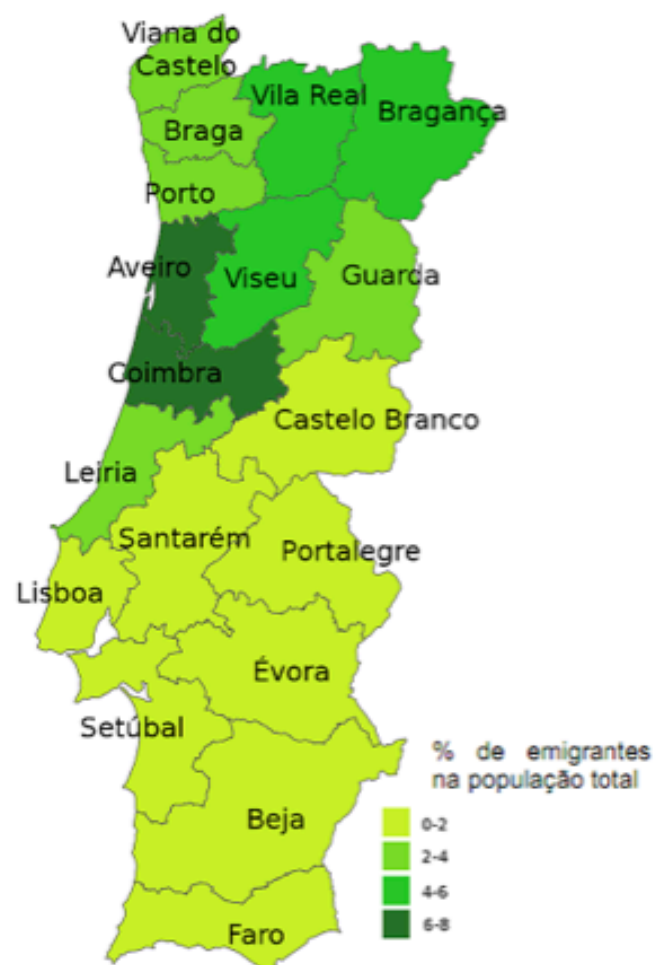

Fonte: Rocha-Trindade e Caeiro (2000). Elaboração: Germano de Castro Granda Neto. 
Com a independência o Brasil passou a adotar políticas incentivadoras da imigração com objetivos diversos. Na segunda metade do século XIX em diante, o fim da escravidão, a expansão da lavoura cafeeira e a adoção de políticas que visavam consolidar o país enquanto nação moderna elucida porque houve incentivo à imigração por parte do Estado.

$\begin{array}{cccc}\text { O Brasil recebeu neste período } & \text { ne } \\ \text { aproximadamente } & \text { cinco } & \text { milhões de } \\ \text { imigrantes, especialmente } & \text { europeus. Os } \\ \text { estrangeiros } & \text { eram } & \text { provenientes, }\end{array}$
principalmente de Portugal, Itália, Espanha, Alemanha, Japão e outros, os quais responderam no período de 1872 a 1972 por $31 \%$ ，30\%， $13 \% ， 4 \% ， 4,6 \%$ e $16 \%$, respectivamente, do total de pessoas que vieram residir no país (BASSANEZI, 1995).

No segundo período dos movimentos migratórios entre Brasil e Portugal a entrada de portugueses no Brasil continuava superando o movimento contrário, mas a sua queda era explícita. Por isso, a partir de meados do século $X X$, pode-se identificar um período de transição.

A partir da década de 1930 o fluxo de estrangeiros para o Brasil diminuiu notavelmente. Concomitantemente aumentou as dinâmicas migratórias internas entre as regiões brasileiras e do campo para a cidade.

Marcou essa fase as políticas de substituição de importações e a construção de grandes obras de engenharia, com financiamento externo, especialmente 0 capital norte-americano. Destaca-se o Plano de Metas do governo JK como um dos símbolos dessa lógica desenvolvimentista. O território brasileiro ganhou novo conteúdo técnico, a indústria o remodelou, conferindo-
Ihe uma nova organização não mais assentada nas bases agrário-exportadora.

O impulso dado por esses investimentos à economia brasileira era concentrado em poucas áreas do território, daí decorre o aprofundamento das desigualdades regionais e sociais. São Paulo reafirma primazia que vinha sendo gestada em período anterior. As áreas mais beneficiadas por essas políticas acabaram por coincidir com as de atração das pessoas provenientes das áreas mais carentes de investimentos.

A ida para a cidade significava a possibilidade de ascender socialmente. Nesse período percebe-se o crescimento de uma classe média ligada ao setor industrial no Brasil, mas igualmente se nota a produção de uma periferia pobre nas cidades (IANNI, 1977).

Nessa fase, a entrada de estrangeiros no Brasil já não contava com o incentivo estatal. Mas o dinamismo econômico brasileiro, os laços históricos culturais, a durabilidade temporal do fluxo, a má situação política da Europa de modo geral, e de Portugal em particular, que passava pelo surgimento da ditadura de Salazar, são elementos que ainda motivavam a migração de portugueses.

Uma transformação considerável iria ocorrer após 1945. A Europa conheceu a partir do fim da Segunda Guerra Mundial elevado dinamismo econômico, decorrente do Plano Marshall e a consolidação do Estado do Bem Estar Social. Tal fato fez mudar a direção dos fluxos de emigração de portugueses, os quais deixaram o alématlântico para voltarem-se ao interior do continente europeu. 
A França foi o país que mais recebeu portugueses no mundo em 1963, tomando a posição histórica do Brasil. Alemanha, Luxemburgo, Suíça, Bélgica, Holanda e Grã-Bretanha também se configuraram como importantes destinos. Nesse período a tendência à permanência perdeu a força, enquanto aumentou os casos de retorno ou visitas assíduas a Portugal, pois os percursos eram mais próximos, baratos e rápidos (ROCHA-TRINDADE, 2001).

A partir da década de 1970, outros processos somaram-se para transformação dos países europeus em países receptores: a descolonização da África e da Ásia, o crescimento populacional dos países pobres e a inclusão mais efetiva destes mesmos países na globalização. Nesse contexto, Portugal registrou fluxos de retorno de portugueses que viviam em suas ex-colônias e verificou aumento paulatino de imigrantes em seu território. Essa nova conjuntura anunciou a alteração da tradicional mobilidade de pessoas entre Brasil e Portugal.

Nos anos 1980, pela primeira vez na história do Brasil, o fenômeno da emigração começou a ganhar volume. Segundo estimativas mais recentes (referentes ao ano de 2008) do Ministério das Relações Exteriores (MRE), os brasileiros que vivem fora do Brasil somam 3.040.993 pessoas, o que corresponde a pouco mais de $1,5 \%$ do total da população brasileira.

O crescimento da emigração refletiu a dinâmica recente do Brasil e pode ser compreendido estabelecendo-se como marco a década de 1980. Encerrou-se, então, um período de grande expansão da economia nacional, pautada especialmente na industrialização através de políticas de substituição de importações. A crise econômica e política tornaram-se vultosas. Esse fenômeno também se fez sentir em outros países da América Latina.

$\mathrm{Na}$ tentativa de controlar a crise econômica difundiram-se no continente americano os mandamentos do Consenso de Washington de 1989. Estes foram expressos sob a forma de adoção de políticas neoliberais, as quais visavam, dentre outras coisas, diminuir a dívida externa, diminuir as despesas do Estado, assegurar investimentos estrangeiros e desregulamentar o mercado.

Ao abandonar o projeto nacional de industrialização, que caracterizou o período de 1930 a 1980, o Brasil conheceu uma fase de tentativa de controle da inflação, por meio de planos econômicos tais como o Plano Cruzado, o Plano Collor e o Plano Real. Apenas o último foi bem sucedido nessa tentativa de controle inflacionário. Contudo, seus benefícios esgotaram-se e o resultado foi a estagnação econômica e o enfraquecimento do parque produtivo brasileiro, o qual foi incapaz de suportar a concorrência externa (GUERRA et al., 2006).

Tudo isso se refletiria fortemente na classe média, a qual, no período imediatamente anterior era majoritariamente assalariada e engajada nas atividades industriais. Se em 1980 a classe média assalariada equivalia a mais de $66 \%$ do total da classe média, em 2000 essa expressão caiu para menos de 60\% (GUERRA et al., 2006).

O enxugamento da classe média assalariada associada ao setor industrial e às instituições públicas foi acompanhado pela emergência de um novo perfil, característico 
de uma sociedade de serviços, em que os contratos se dão de maneira indireta e na esfera das redes de produção mundiais. A "segurança" dos contratos assalariados deu lugar à "informalidade no exercício do trabalho e na crescente auto-ocupação (free lancer, empresa sem empregado, organizações não governamentais, entre outras)" (GUERRA et al. 2006, p. 24). Este novo perfil no interior da classe média é dotado de valores cosmopolitas e individualistas característicos da fase atual do capitalismo e que acaba por se difundir no grupo como um todo. Contudo, mantêm-se os tradicionais desejos de consumo, status social e poder que sempre marcaram esta camada social brasileira.

A redução de renda atingiu a classe média até 2005. Daí em diante, a renda voltou a dar sinais de recuperação. Até esse momento, a falta de perspectiva de melhoria levou a busca por melhoria de condições de vida fora do país. Em um segundo momento, a partir de 2002, porém, houve aumentos significativos da renda das classes mais baixas devido, especialmente ao aumento real do salário mínimo e programas de transferência de renda, como o Bolsa Família, por exemplo. Emerge, assim, uma nova classe média no Brasil que mudará o perfil dos migrantes.
Esses pertencem predominantemente a classe média ou média inferior: "são migrantes com escolarização, em sua maioria de nível médio e dispõem de capital para utilização do meio de transporte rápido avião" (ROSSINI, 2008, p. 344). Além disso, podem arcar com os gastos iniciais, o que inclui moradia, alimentação, transporte, até conseguirem um trabalho que possibilite sua permanência no novo país.

A experiência de viver no exterior é repleta de significações positivas no Brasil. Nesse sentido, morar em algum país europeu, nos Estados Unidos, ou em outros países ricos constitui-se na ilusão de maior acesso ao consumo e prestígio social no Brasil, ainda que isso signifique para o migrante, condições de vida piores do que a anterior.

Embora os dados sejam limitados para expressar o real volume da emigração brasileira, eles permitem identificar os principais destinos em termos numéricos. Os Estados Unidos, União Europeia, Japão e países fronteiriços, especialmente Paraguai, destacam-se como principais países de destino. Cerca de $75 \%$ dos fluxos são direcionados para países do hemisfério norte, sendo que $27 \%$ do total de brasileiros que migram vão viver na Europa, conforme é possível observar no gráfico a seguir: 
Gráfico 1 - Percentual de imigrantes brasileiros em relação aos dez principais países receptores - 2009

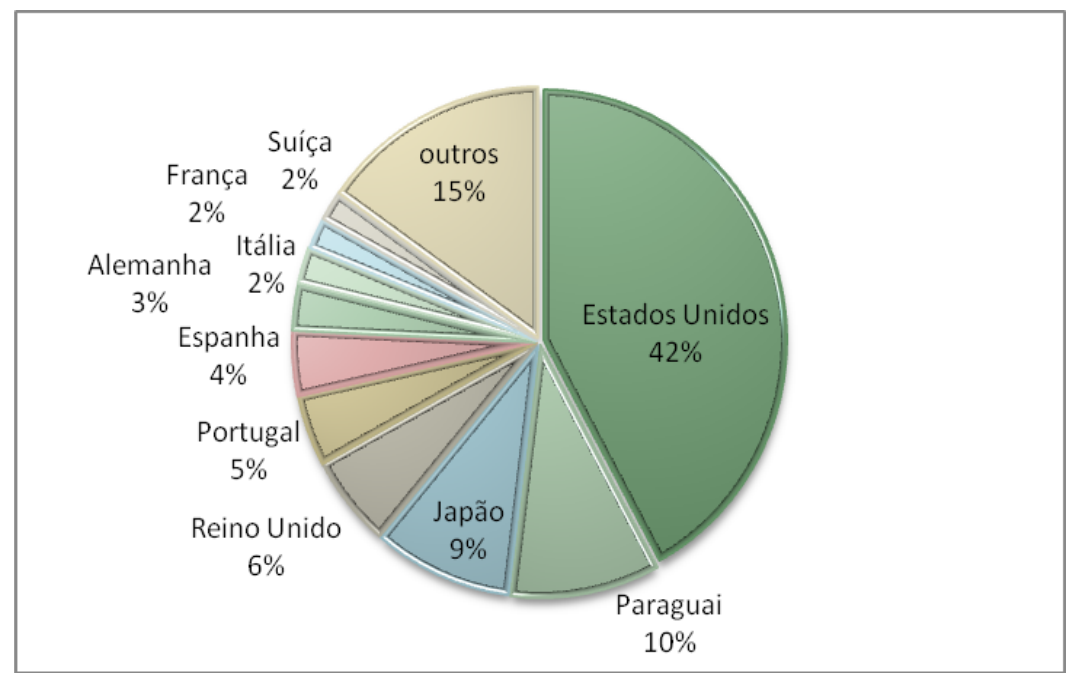

Fonte: Ministério das Relações Exteriores. Brasileiros no Mundo: Estimativas. Segunda Edição, Setembro de 2009. Elaboração Própria.

Neste panorama, interessa aqui os brasileiros que tem como destino Portugal, quinto país que mais acolhe brasileiros no mundo e segundo principal receptor de brasileiros que vão para a Europa. A importância desse fluxo ainda é mais saliente se se considera 0 peso da comunidade brasileira em relação à população total residente no país, relação essa evidenciada na Tabela 1.

Tabela 1 - Participação dos brasileiros no total de habitantes dos dez principais países receptores - 2009

\begin{tabular}{lccc}
\hline País & $\begin{array}{c}\text { Brasileiros } \\
\text { (número absoluto) }\end{array}$ & Total de habitantes do país & $\begin{array}{c}\text { Participação brasileira } \\
\text { no total dos habitantes } \\
\text { do país }\end{array}$ \\
\hline Paraguai & 300.000 & 6.348 .917 & $4,70 \%$ \\
\hline Portugal & 137.600 & 10.707 .130 & $1,30 \%$ \\
\hline Suíça & 57.500 & 7.567 .661 & $0,75 \%$ \\
\hline Estados Unidos & 1.280 .000 & 314.658 .780 & $0,40 \%$ \\
\hline Reino Unido & 180.000 & 61.565 .422 & $0,29 \%$ \\
\hline Espanha & 125.000 & 44.903 .659 & $0,27 \%$ \\
\hline Japão & 280.000 & 127.156 .225 & $0,22 \%$ \\
\hline Itália & 70.000 & 59.870 .123 & $0,11 \%$ \\
\hline Alemanha & 89.000 & 82.166 .671 & $0,10 \%$ \\
\hline França & 60.000 & 62.342 .668 & $0,09 \%$ \\
\hline
\end{tabular}

Fonte: Ministério das Relações Exteriores. Brasileiros no Mundo: Estimativas. 2. ed. set. 2009. United Nations. Indicator on Population. In: United Nations Statistics Division. Demographic and Social Statistics. Statistical Products and Databases. Social Indicators, 2009. Organização: Aline Lima Santos

\section{Perfil dos migrantes brasileiros em Portugal}

A ancestralidade, a proximidade histórico-cultural, a língua em comum são elementos que favoreceram a ida de imigrantes lusófonos para Portugal a partir dos anos 1970. Em 1986, a adesão desse país à Comunidade Econômica Europeia 
aumentou as perspectivas de crescimento econômico português e os esforços para modernização do país. Posteriormente, a adoção do euro e sua atrativa taxa de cambio e os atentados de onze de setembro aos Estados Unidos, consolidaram Portugal como destino de brasileiros na Europa (SANTOS, 2010).

Tais fatos repercutiram em duas ondas migratórias do Brasil para Portugal. Em um primeiro momento, os fluxos caracterizaram-se pelo retorno de portugueses, muitos aposentados, acompanhados de esposas ou esposos brasileiros e filhos. Esse fluxo para Portugal foi se intensificando nas décadas seguintes e seus conteúdos foram se transformando.

$\mathrm{Na}$ primeira onda migratória, os imigrantes brasileiros direcionaram-se às áreas que tradicionalmente foram emissoras de portugueses para o Brasil (Figura 1). Trata-se, deste modo, de uma distribuição mais concentrada no norte litoral. Além disso, a porcentagem da população não ativa era elevada, chegando a 48\% em 1991 (MALHEIROS, 2007).

De maneira geral, essa comunidade era formada por pessoas oriundas da classe média que possuíam elevado nível de instrução. Dentre os 52\% que trabalhavam, a maior parte lograva engajar-se em segmentos compatíveis com sua formação.

Nesse período era comum a presença brasileira em segmentos do mercado de trabalho exigentes de alta qualificação (MALHEIROS, 2007).

Em 1994, a estabilidade econômica trazida pelo Plano Real diminuiu o ritmo da emigração para Portugal, levando a diminuição da comunidade brasileira em 1997 e 1998. No entanto, na segunda metade da década de 1990, o mundo enfrentava graves crises financeiras, nomeadamente, a do México (dezembro de 1994), da Ásia (outubro de 1997) e da Rússia (agosto de 1998), economias que dependiam, assim como o Brasil, de capitais estrangeiros para financiar os déficits comerciais e as contas do governo. Tais crises evidenciaram a vulnerabilidade do Brasil diante dos fluxos de capitais internacionais, muitas vezes meramente especulativos.

Esse contexto turbulento para a economia foi enfrentado no Brasil adotandose um sistema cambial mais flexível, isto é, desvalorização do real frente ao dólar, o aumento na taxa de juros e o corte dos gastos do governo. Tudo isso colaborou para a estagnação do crescimento econômico e o aumento da taxa de desemprego, a qual atingiu 19\% em junho de 1998, no estado de São Paulo (DIEESE, 1998).

Tais circunstâncias deram um novo fôlego ao fluxo de brasileiros para Portugal. Identifica-se no período pós 1998 uma segunda onda da migração brasileira. Nessa nova fase, a população ativa passou a ser dominante, representando, em 2001, 74\% do total da população brasileira residente em Portugal. Trata-se, então, de um fluxo majoritariamente laboral, o que irá se refletir na distribuição territorial, que se tornou mais concentrada na área de Lisboa. O nível de instrução das pessoas imigrantes a partir de então é um pouco mais baixo comparativamente à primeira onda e seu engajamento no mercado de trabalho é maior nos segmentos menos qualificados (MALHEIROS, 2007). O Quadro 1 sintetiza as diferenças gerais das duas onda. 
Quadro 1 - Migração brasileira para Portugal

\begin{tabular}{ccc}
\hline Características & Primeira onda & Segunda onda \\
\hline Fase & 1980 a meados de 1990 & A partir de 1998 \\
\hline Essência do fluxo & Refluxo & Laboral \\
\hline Distribuição no território & Concentrada no norte litoral & Concentrada em Lisboa \\
\hline População ativa & Não dominante & Dominante \\
\hline $\begin{array}{c}\text { Origem na estrutura social } \\
\text { brasileira }\end{array}$ & Classe média & Classe média e média-baixa \\
\hline $\begin{array}{c}\text { Nível de instrução } \\
\text { Inserção no mercado de } \\
\text { trabalho }\end{array}$ & $\begin{array}{c}\text { Slevado } \\
\text { qualificação }\end{array}$ & Médio \\
\hline
\end{tabular}

Fonte: Malheiros (2007). Organização: Aline Lima Santos.

Tanto na primeira como na segunda onda, predominou a participação dos brasileiros no setor terciário. Na primeira onda destacaram-se os setores da área da saúde, técnicos em informática, marketing e publicidade (GÓIS; MARQUES, 2007; SANTOS, 2010). Na segunda, por sua vez, comércio, restaurantes, serviços domésticos, serviços de limpeza e construção civil foram setores responsáveis pela maior parte da ocupação deste grupo estrangeiro. Em suma, embora a presença de brasileiros em postos de trabalho altamente qualificados seja um fato, seu peso diminuiu sensivelmente na segunda onda migratória. Por outro lado houve aumento expressivo da participação de brasileiros em setores socialmente desvalorizados devido à baixa remuneração e precariedade que os caracteriza em Portugal. Tais setores são amplamente sujeitos aos ciclos de crescimento (MALHEIROS, 2007).

Pode-se, inferir daí que hoje a crise econômica, verificada nos países europeus e em Portugal, particularmente, atinja fortemente os migrantes brasileiros, tornando suas vidas mais difíceis e instigando o retorno de muitos. Segundo dados da Organização Internacional para as Migrações
(OIM), cerca de $80 \%$ das pessoas que em Portugal solicitam o retorno ao país de origem são brasileiras. O número de pedidos de brasileiros para o Programa de Retorno Voluntário em Portugal cresceu de 252 em 2006 para 1011 em 2009 (OIM, 2009). A este número somam-se as pessoas que retornam com recursos próprios.

Apesar disso, de 2009 para 2010 a comunidade brasileira em Portugal passou de 116.220 para 119.363 pessoas. Em 2010, os brasileiros representaram $26,81 \%$ do total de estrangeiros, 0 que significou, comparativamente ao ano anterior, incremento em quase $2 \%$ do total desta participação. No mesmo período, as comunidades estrangeiras tradicionais em Portugal, provenientes de Cabo Verde, Angola e Guiné Bissau, tiveram decréscimo de seu peso relativo (SEF, 2011).

Diante destes fatos, convém observar e analisar qual o enquadramento normativo das migrações de brasileiros para Portugal e quais são as políticas migratórias adotadas pelo Brasil e por Portugal. 
Políticas migratórias no país de origem e de destino

O arcabouço normativo referente a entrada e permanência de brasileiros em Portugal e de portugueses no Brasil pode ser considerado um incentivo para a existência do fluxo migratório aqui analisado. 0 documento mais recente a esse respeito é o Tratado de Amizade, Cooperação e Consulta entre a República Portuguesa e a República Federativa do Brasil assinado em 22 de abril de 2000, em virtude das comemorações do "descobrimento do Brasil".

Nele estabeleceu-se a isenção de visto pelo período de 90 dias aos que desejam entrar no território da outra parte contratante para fins culturais, empresariais, jornalísticos ou turísticos. E regulamenta 0 estatuto de igualdade, cujos beneficiários, brasileiros em Portugal e portugueses no Brasil, tem os mesmos direitos e deveres que os nacionais desses estados (MAGALHÃES, 1999).

O status especial dado ao migrante brasileiro em território português é fruto, em certa medida, de acordos diplomáticos consolidados desde o reconhecimento de nossa independência. Seguramente essa história acumulada de acordos que colocou Brasil e Portugal como "nações amigas" (MAGALHÃES, 1999). Ainda que os fatos nem sempre as confirmem como tal, esta relação tem repercussões no sentido de incentivar as decisões de emigrar.

Contudo, os acordos relativos aos brasileiros em Portugal e aos portugueses no Brasil são, especialmente a partir dos anos 1990, subordinados à integração europeia. Portugal, como membro da União Europeia
(UE), busca conciliar os interesses do bloco com seus interesses particulares.

Em 1991, Portugal adere aos Acordos Schengen, que regula a livre circulação de pessoas no espaço comunitário europeu. Suas políticas de imigração passaram, a partir de então, a privilegiar migrantes provenientes dos demais Estados membros. Conjuntamente tais Estados procuram definir políticas comuns aplicadas a países terceiros. Ao mesmo tempo, porém, Portugal opta por dar preferência a migrantes provenientes dos Países Africanos de Língua Portuguesa (PALOP) e do Brasil, o que ocorre, sobretudo, por motivações políticas e históricas.

Por isso Portugal não adere completamente aos direcionamentos da UE em detrimento de suas políticas nacionais e de tratados já estabelecidos com outras nações. É notório seu esforço no sentido de encontrar um equilíbrio entre os interesses divergentes que envolvem a questão migratória.

Essa postura portuguesa significou aos brasileiros a transformação desse país em uma porta de entrada para o restante dos países da Europa. Alguns migrantes entram em Portugal com a intenção de aí se estabelecerem tempo suficiente para adquirir documentos que os permitam ir para outro destino europeu. Esse projeto migratório em duas etapas é justificado pela ideia de que, sendo brasileiro, é mais fácil entrar em Portugal e regularizar-se, comparativamente a outros países europeus.

Todavia, há casos de migrantes brasileiros que foram para outros países e, em decorrência das dificuldades encontradas, preferiram voltar para Portugal. Isso demonstra que nem sempre o projeto inicial 
de migração em etapas é bem sucedido, além disso, nem sempre ele é efetivado. A tendência é o estabelecimento definitivo nesse país ou o retorno ao Brasil.

Além da adesão aos Acordos Schengen, deve-se destacar do mesmo modo o acirramento das relações econômicas entre Brasil e Portugal. Isso se deu, sobretudo, na década de 1990, período de marcado por privatizações no Brasil. Nesta fase houve aumentou expressivo dos investimentos portugueses no setor de telecomunicações, acarretando, portanto, uma reaproximação entre os dois países. Atualmente, ambos esforçam-se no sentido de consolidar tais relações econômicas bilaterais com a finalidade de extrapolá-las tanto para o Mercosul como para União Europeia. Evidentemente, tal aproximação também é um incentivador dos fluxos de um país para o outro.

Tais movimentos articulados revigoram a histórica porosidade das fronteiras entre Brasil e Portugal (LAFER, 2003; BECK, 1999). Essa permeabilidade aos fluxos das mais diversas naturezas entre os dois países é incrementada pelas práticas transnacionais cotidianas dos migrantes, que conectam e reúnem país de emigração e de imigração.

As práticas transnacionais dos migrantes, há séculos, constituem os movimentos populacionais internacionais. Contudo, as bases técnicas hoje disponíveis permitem viver e agir simultaneamente em lugares distintos de modo instantâneo e independente da distância (SANTOS 2002; BECK, 1999).

Por consequência, uma das características das migrações internacionais contemporâneas é que a conservação dos vínculos com o país de origem torna-se mais intensa. Isso é expresso de diversas maneiras, como demonstram as remessas, as frequentes visitas, os investimentos em bens imóveis, o associativismo, dentre outras práticas.

Os brasileiros em Portugal não fogem a essa característica. Embora presentes em território português, a inserção dessa população estrangeira se dá sem que, muitas vezes, os migrantes abram mão de sua vinculação, mesmo que fisicamente distante com o Brasil.

Uma expressão de que os emigrantes brasileiros não abandonam completamente o país de origem é a existência de inúmeras associações brasileiras no mundo. Dentre elas, predominam as igrejas, principalmente evangélicas. Há também aquelas que promovem a cultura e a língua portuguesa para os descendentes, e as que privilegiam os esportes, em especial a capoeira e o futebol. São em menor número as que extrapolaram tais objetivos de pertencimento cultural comum e ajuda socioeconômica para assumirem como primordiais as questões políticas que envolvem os direitos de cidadania dos migrantes.

A maior parte das associações brasileiras existentes em Portugal, porém, atua na afirmação política das causas dos migrantes, o que se constitui em uma peculiaridade dessa comunidade brasileira no exterior. A Casa do Brasil de Lisboa (CBL) foi pioneira nesse sentido, focando sua prática na defesa e luta pela cidadania. Seu empenho tem sido o de aglutinar as outras associações brasileiras, mantendo também o diálogo com as associações representantes 
das demais comunidades estrangeiras em Portugal.

O que se nota no país é que a mobilização das associações de imigrantes tem logrado alguns êxitos junto ao Estado receptor. Isso se relaciona a articulação das associações com as organizações não governamentais, as quais têm conquistado relevância como interventoras sociais.

Além disso, o Estado português, desde os anos 1990, reconheceu o associativismo imigrante como interlocutor e estimulador do processo de integração dos estrangeiros, abrindo-se, portanto, ao diálogo. Certamente esse reconhecimento é fortemente influenciado pela experiência associativa das comunidades portuguesas no exterior, com as quais o Estado mantém relações privilegiadas. Soma-se, ainda, a existência de uma história compartilhada de experiências de imigração com os portugueses retornados do Brasil, muitos dos quais procuraram manter seus vínculos com o país que os recebeu. A própria CBL conta com a colaboração de portugueses e outros estrangeiros.

Portugal admite-se como país de imigração e busca gerir esse fenômeno de modo a não prejudicar a coesão interna de sua sociedade. Assim, o país assume-se cada vez mais como intercultural, buscando promover o diálogo entre os diferentes imigrantes e os nacionais que constituem sua população, ainda que existam internamente setores da sociedade mais ou menos simpáticos à entrada de estrangeiros.

A regularização dos imigrantes em território português está submetida à comprovação de atividade profissional remunerada. Possuir um contrato de trabalho em Portugal é condição para tornar-se imigrante em situação regular. Cerca de 90\% dos estrangeiros de países terceiros que atualmente residem em condições regulares em Portugal foram beneficiados por esses processos, sendo um percentual significativo composto por nacionais do Brasil.

As normas referentes à entrada de estrangeiros em Portugal permitem que a maioria dos imigrantes entre no país, de modo geral, com vistos de turista, passagem de volta, comprovante de renda para permanência no período pretendido e dados de reserva da hospedagem. Satisfeitas tais condições, pode-se ficar em Portugal por até três meses. Nesse tempo, os imigrantes tentam encontrar trabalho que Ihes ofereça contrato, já que isso possibilitará permanência no país de modo regular.

Tal estratégia é uma prática comum entre os brasileiros. No entanto, nem sempre três meses é tempo suficiente para que os imigrantes encontrem trabalho que lhes conceda contrato e há casos em que as promessas desse documento por parte dos patrões tornam-se verdadeiras chantagens.

Apesar destes problemas, todo 0 conjunto de medidas que compõem as políticas de imigração em Portugal e as práticas de entidades e dos próprios imigrantes colocam o país como dos mais favoráveis à integração comparativamente aos demais países da UE. Essa foi a conclusão a que chegou o Migrant Integration Policy Index (Mipex), responsável pela avaliação das políticas de integração dos imigrantes dos países europeus (UE-25) e ainda Canadá, Noruega e Suíça.

O Mipex considera para as análises o acesso dos imigrantes ao mercado de 
trabalho; as condições para o reagrupamento familiar; a possibilidade de residência de longa duração; a participação política; a aquisição de nacionalidade e as políticas antidiscriminação. Levando em conta diversos fatores em cada um desses componentes, elabora-se uma escala que varia de 0 a 100, onde a maior pontuação representa as melhores práticas possíveis de integração.

Figura 2 - Portugal e as políticas para integração - situação em 2006

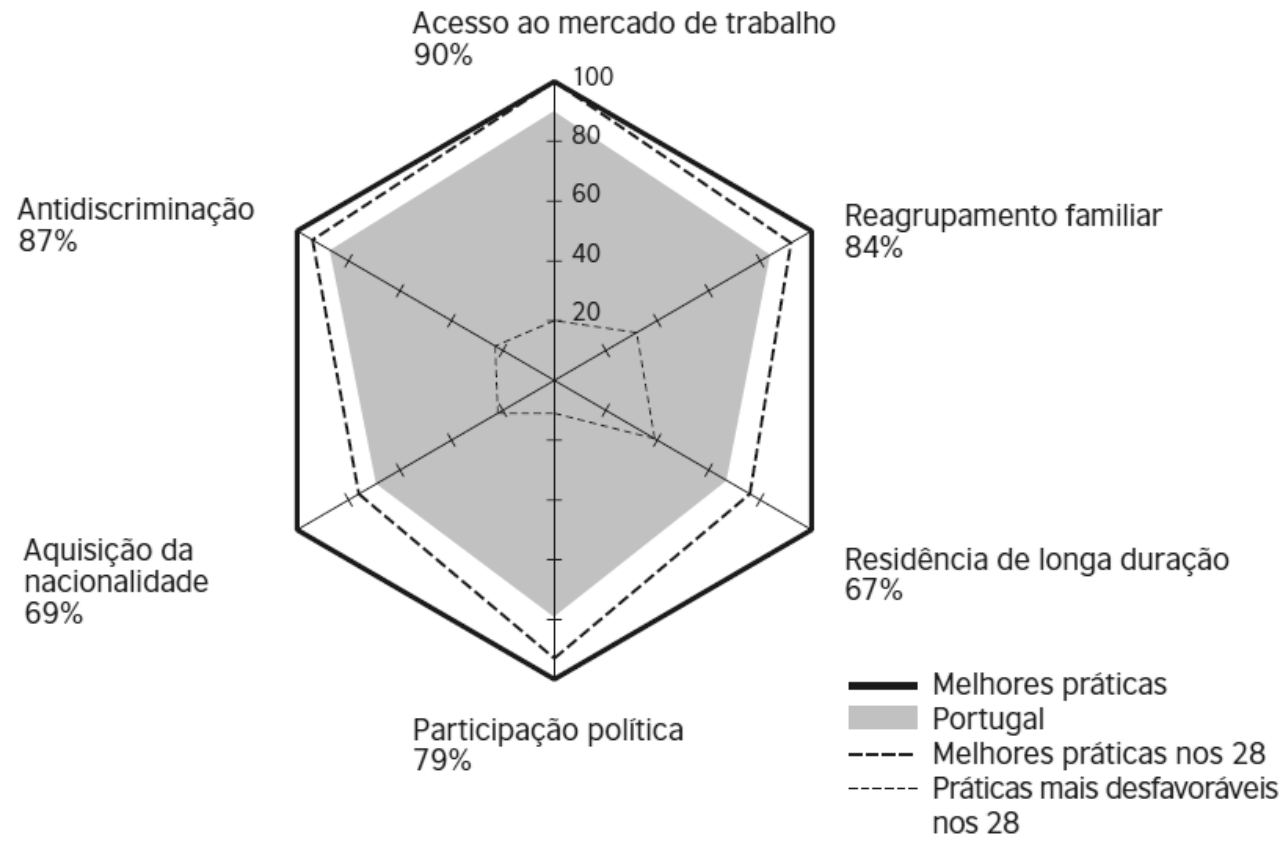

Fonte: Niessen (2007, p. 146).

As políticas portuguesas referentes ao acesso do imigrante ao mercado de trabalho e a antidiscriminação são os pontos fortes para promoção da integração no país. Portugal é o segundo país da UE que mais favorece a criação de iguais oportunidades de trabalho para imigrantes e nacionais; contudo, o reconhecimento das competências dos trabalhadores imigrantes é sujeito aos acordos com o país de origem e frequentemente dependem de processos demorados, caros e burocráticos. Quanto à antidiscriminação, o quadro legislativo português baseia-se em definições e conceitos claros, o que é positivo, mas o Mipex sugere melhorias nos mecanismos de implementação, como a maior participação das ONGs no apoio às vítimas (NIESSEN, 2007).
Com relação às políticas de aquisição de nacionalidade e residência de longa duração, Portugal ocupa a quinta e a terceira posição, respectivamente, dentre os demais países. São, portanto, as mais limitadas para promoção da integração dos imigrantes. Essa limitação, aliás, é uma característica comum na UE-25, especialmente após a década de 1970, momento em que o elevado número de imigrantes em alguns países os fez rever as políticas de nacionalidade e de imigração (REIS, 2003).

Tais barreiras à integração certamente baseiam-se no fato de que no sistema internacional tradicional a cidadania é atrelada ao Estado territorial. Os Estados controlam a identidade das pessoas na medida em que atribuem aos nascidos em 
seu território sua nacionalidade, de maneira independente da vontade dos mesmos (REIS, 2003). As pessoas, portanto, inserem-se em um "contêiner social" com o qual compartilham uma identidade, imposta e incorporada e construída em movimentos de incessante ir e vir.

Nessa perspectiva, o emigrante fica praticamente desprovido das garantias de concessão de seus direitos por parte do Estado, visto que tal concessão é limitada ao seu território. Por outro lado, as obrigações da pessoa para com a sociedade e o Estado quase que desaparecem quando ela o deixa.

Decorre daí que tradicionalmente, "são os países de imigração que, ao menos em teoria, controlam as migrações internacionais, já que definem o número e as categorias das pessoas que entram" (ROCHATRINDADE, 1995, p. 314). O Estado de origem pouco pode fazer pelos emigrados, suas ações muitas vezes limita-se à defesa da mobilidade geográfica e profissional, a igualdade de tratamento em relação aos nacionais do país receptor, a garantia de preservação da identidade cultural do imigrante, facilidades no de envio de remessas, dentre outros.

Entretanto, as fragilidades e consequente enfraquecimento do Estado de Bem-Estar-Social nos países ricos e a adoção de políticas neoliberais em países ricos e pobres culminaram no fortalecimento do poder da sociedade civil organizada em todo o mundo. No momento em que o Estado passou a exercer debilmente suas funções sociais ou mesmo abdicá-las, o descontentamento e descrédito levaram à pulverização de iniciativas que visavam compensar as perdas. As organizações originadas por essas iniciativas ganharam cada vez mais espaço de participação política, tornando-se atores políticos importantes tanto na escala nacional como na internacional.

Muitas dessas entidades envolveram-se com a temática migratória de modo direto ou indireto e colaboraram para transformação dos discursos políticos referentes à migração. Trata-se, pois, de um elemento que diferencia o sistema internacional do período contemporâneo, isto é, aquilo que Domenech (2008) denomina "cidadanização da política migratória".

Em decorrência disso, hoje, os países de origem são chamados a participar mais ativamente dos debates sobre as migrações. Assumem, deste modo, o consenso e a corresponsabilidade como palavras de ordem em suas relações com os países receptores. Há, por isso, tendência à cooperação, multilateralização e até mesmo transnacionalização da formulação das políticas migratórias, as quais passam a considerar as organizações da sociedade civil como parte das estratégias de aplicação das medidas que visam atingir o fim proposto.

Atuação da CBL e demais associações brasileiras no mundo deram visibilidade à emigração brasileira junto ao Estado de origem. Dessa forma, colaboraram intensamente para uma mudança de postura do Estado brasileiro quanto aos emigrantes.

$\mathrm{Na}$ década de 2000 foram implementados programas de regularização; acordos previdenciários, informatização e reforma do sistema consular; canais de comunicação direta com os emigrantes por meio do Portal Consular, do Portal das Comunidades, da Ouvidoria Consular; criação 
do site www.brasileirosnomundo.mre.gov.br, que disponibiliza diversas informações de interesse dos emigrantes; e, por fim, assinado o Decreto n07.214 de 15 de junho de 2010. Com esse documento instaura-se explicitamente no Brasil uma política de Estado para os emigrantes.

Nota-se, diante do exposto, que Brasil e Portugal compartilham uma população para quem vale, ao mesmo tempo, o "estar aqui" e o "estar lá". Justamente por sua condição híbrida, a soberania exercida sob essa população também é compartilhada entre país de origem e país receptor, que para isso lançam mão de acordos diversos. Constata-se assim que os aspectos tradicionais das relações entre território, Estado e população não desapareceram, mas adquiriram complexidade.

$$
\text { A soberania compartilhada é }
$$
subordinada as estratégias de inserção na divisão internacional do trabalho e participação geopolítica no sistema internacional, sendo a população um componente das mesmas. Nessa perspectiva as migrações podem ser geridas de modo a fortalecer vínculos comerciais e culminar na expansão da influência de um país no mundo, colaborando para a promoção de um poder brando, tanto do país receptor como do país de origem.

\section{Referências bibliográficas}

BARATA, O. S. Demografia e sistema internacional. Lisboa: Instituto Superior de Ciências Sociais e Políticas da Universidade Técnica de Lisboa, 2003.

BASSANEZI, M. S. C. B. Imigrações internacionais no Brasil: um panorama histórico. In: PATARRA, $\mathrm{N}$. L. (Coord.). Emigração e imigração internacionais no Brasil contemporâneo. 2. ed. São Paulo: FNUAP, 1995, p. 1-38.

BECK, U. O que é globalização? Equívocos do globalismo: respostas à globalização. São Paulo: Paz e Terra, 1999.

\section{DIEESE. A conjuntura econômica recente:} crise financeira e vulnerabilidade do real. São Paulo: Dieese, 1998. Disponível em: <http://dieese.org.br/esp/real/crisere al.xml>. Acesso em: 25 set. 2011.

DOMENECH, E. La ciudadanización de la política migratoria en la región sudamericana: vicisitudes de la agenda global. In: NOVICK, S. (Comp.). Las migraciones en América Latina. Buenos Aires: Catálogos, 2008.
GÓIS, P.; MARQUES, J. C. Estudo prospectivo sobre imigrantes qualificados em Portugal. Lisboa: Acidi, 2007. (Coleção Estudos OI, 24.)

GUERRA, A. et al. (Orgs.). Atlas da Nova Estratificação Social no Brasil, v. 1. Classe média: desenvolvimento e crise. São Paulo: Cortez, 2006.

IANNI, O. Estado e planejamento econômico no Brasil (1930-1970). Rio de Janeiro, 1977.

LAFER, C. Relações Brasil-Portugal: passado, presente, futuro. In: ABDALA JR., B. (Org.). Incertas relações: Brasil e Portugal no século XX. São Paulo: Editora Senac São Paulo, 2003.

MAGALHÃES, J. C. Breve história das relações diplomáticas entre Brasil e Portugal. São Paulo: Paz e Terra, 1999.

MALHEIROS, J. M. (Org.). Imigração brasileira em Portugal. Lisboa: Acidi, 2007. (Coleção Comunidades, 1.)

MRE. Ministério das Relações Exteriores. Brasileiros no mundo: estimativas. 
2. ed. Brasília, set. 2009. Disponível em: <www.brasileirosnomundo. mre.gov.br>. Acesso em: 13 set. 2011.

NIESSEN, J. et al. Migrant Integration Policy Index. Bruxelas: British Council \& Migration Policy Group, 2007.

OIM. Perfil migratório do Brasil, 2009. Genebra: Organização Internacional para as Migrações, 2010.

REIS, R. Construindo fronteiras: políticas de imigração na França e nos Estados Unidos (1980-1998). Tese (Doutorado em Ciência Política) Faculdade de Filosofia, Letras e Ciências Humanas, Universidade de São Paulo, 2003.

ROCHA-TRINDADE, M. B. História das migrações portuguesas. In: Janus 2001. Anuário de Relações Exteriores. Lisboa: Público \& Universidade de Lisboa, 2002, p.170173.

. História da imigração em Portugal I e II. In: Janus 2001. Anuário de Relações Exteriores. Lisboa: Público \& Universidade de Lisboa, 2001, p.6970 .

Sociologia das migrações. Lisboa: Universidade Aberta, 1995.

. Emigração. In: Dicionário

Ilustrado da História de Portugal, v. 1. Lisboa: Alfa, 1986, p.205-207.
RODRIGUES, T. F. História da População Portuguesa. Porto: Afrontamento, 2009.

ROSSINI, R. E. A presença do ausente: migrantes nikkeis do Brasil no Japão, migrantes japoneses no Brasil. In: REIS, Raquel (Org.). Actas do Congresso Solidariedade Intergeracional. Lisboa: FCT/CEMRI/Universidade Aberta, 2008.

\section{SANTOS, A. L. Mudança de vento: a} migração do Brasil para Portugal no fim do século $X X$ e início do século XXI. Dissertação (Mestrado) Faculdade de Filosofia, Letras e Ciências Humanas, Universidade de São Paulo, São Paulo, 2010.

SANTOS, M. Para que a geografia mude sem ficar a mesma coisa. RA'E GA, Curitiba: Editora UFPR, n. 9, 2005. P. 125-134.

A natureza do espaço: espaço e tempo, razão e emoção. São Paulo: Edusp, 2002.

. Por uma outra globalização: do pensamento único à consciência universal. São Paulo: Record, 2001.

SASSEN, S. Los espectros de la globalización. Buenos Aires: Fondo de Cultura Económica, 2003.

SEF. Relatório Estatístico 2010. Lisboa: Núcleo de Planejamento do Serviço de Estrangeiros e Fronteiras, 2011. 